\title{
LA BARRANCA Y LA ALBERCA
}

Eran vecinas todo el día y lo más inquietante, la noche entera.

Separadas, por la tierra de nadie, que esconde a la barranca y que engaña a sus presas, eran aliadas clandestinas del peligro, siempre sucio y salvaje.

La alberca, prometedora, la barranca, cumplidora y paciente, ahora se juntan y tejen, sin sueños, mis pesadillas:

la barranca, sin la alberca, se presenta de noche, segura de la ley de la caída: 


\author{
ella no distingue \\ de basura y de gente: \\ todo desaparece \\ pudriéndose, \\ entre sus fauces \\ que no digieren, \\ ni entierran... \\ tantos años de tentar \\ a las barrancas, \\ para desbarrancarse \\ y que no vengan \\ los zopilotes, \\ todavía, \\ a llevarme difunto, \\ en su vientre, \\ que se eleva \\ y defeca.
}

